the mathematical treatment and in some of the assumptions made were pointed out, and it was concluded that these vitiated the correctness of the theory as a whole. Due to the lateness of the hour, a paper on "Mineralogy and Petrography of the Ordovician 'Metabentonites' and related Limestones", by C. E. Weaver and Dr. T. F. Bates (Pennsylvania State College), was read by title only.

This discussion left little doubt as to the importance of the contributions being made by clay mineralogists to geology, and especially to sedimentary petrology; but the general note was that the problems yet to be solved far exceed those to which present knowledge supplies an answer. A fitting conclusion, therefore, was the plea of Prof. Taylor that clay mineralogists should in all papers supply the fullest available geological data.

R. C. Mackenzie

${ }^{1}$ Millot, G., Geol. Appl. et Prospect. Minière, 2, Nos, 2, 3 and 4 (1949). ${ }^{2}$ Grim, R. E., Dietz, R. S., and Bradley, W. F., Bull. Geol. Soc. Amer. 60, $1785(1949)$

see Nagelschmidt, G., Imp. Bur. Soil Sci., Tech. Comm. No. 42, 2 (1944).

' Bowen, N. L., J. Geol., 30, 177 (1922); “The Evolution of Igneous Rocks", Chap, 5, 54 (1928).

s Wilkinson, P., Clay Min. Bull., No, 4, 122 (1950).

Mackenzie, R. C., Walker, G. F., and Hart, R., Min. Mag., 28, 704 (1949).

' See Nature, 168, 107 (1951).

\& Arens, P. I., Dissertation, Landbouwhogeschool, Wageningen (1951).

\section{FOOD PROTECTION IN THE UNITED STATES}

T

HE Delaney Committee established in 1950 by

the United States Congress is continuing its inquiry into the use of chemical additives in food processing and into the allied problem of the contamination of foodstuffs by residues from pesticides and detergents. The earlier sessions of this Committee $^{1}$ revealed that much of the experimental work on the toxicity of chemical additives had given results which were far from conclusive. Biochemists and physiologists in the universities and in foodmanufacturing concerns tended to adopt an extremely cautious attitude in their interpretation of these findings; other scientific workers adopted a somewhat different point of view. This division of opinion constituted a challenge to the objectivity of the scientific witness; a challenge which demanded action by an independent body able to discuss the difficult and complex problems in academic calm and with academic freedom.

Thus there came into being in 1951 a Food Protection Committee formed on the initiative of the Food and Nutrition Board of the National Research Council--itself established in 1916 as an offshoot of the National Academy of Sciences for the purpose of providing panels of independent advisers to the United States Government. This Council is representative of more than ninety major scientific societies and includes business men as well as scientific workers and technologists.

The Food Protection Committee has outlined its programme under four headings as follows. (1) It will assemble scientific information on both incidental and intentional chemical additives which are used, or proposed for use, in or on foods and will summarize and evaluate this information and make its conclusions available in usable form to those interested. (2) It will advise and assist industry and Federal and State government agencies in the integration of research on the utilization of chemicals in food production, processing and preservation, and will promote additional research, by existing agencies, which in the opinion of the Committee appears desirable in the public interest. The Committee itself, however, does not propose to conduct or finance research. (3) It will seek to develop guiding principles and standardized procedures essential for safeguarding food. (4) It will encourage and aid in the distribution of accurate scientific information to the general public.

Under the chairmanship of Prof. H. E. Longenecker, dean of the Graduate School of the University of Pittsburgh, the Committee consists of eleven men of science all holding academic appointments in different universities and in different fields-ranging from human pathology and nutrition, through biochemistry and pharmacology to entomology and plant pathology. Four groups have been established (each under the chairmanship of a member of the Committee) to deal with specific inquiries on the following respective subjects : toxicology, pesticides, food technology and chemistry. The groups are composed primarily of men of science in educational posts, with a lesser number drawn from research associations and other bodies. They are assisted by four advisory panels : from industry, from trade associations and research foundations, from government agencies, and from scientific and technical bodies. This relatively complicated structure is designed to ensure, on one hand, objectivity in decisions and, on the other, channels for the present. ation of divergent points of view and interests.

A recently published statement ${ }^{2}$ of the Food Protection Committee gives a broad survey of the problems under discussion and reveals the efforts being made to provide the equivalent of a pharmacopoeia listing the chemical additives in use and their biological effects on experimental animals and on man. This is a project which should prove of permanent value and might well be a fruitful field of international co-operation between scientific workers in Great Britain and their colleagues across the Atlantic.

'Aylward, F., Nature, 168, i48 (1951).

"Food Protection Committee, "Use of Chemical Additives in Foods" (Nat. Res. Council, 2101 Constitution Avenue, Washington 25, D.C., 1951).

\section{ORIGIN AND DISTRIBUTION OF CULTIVATED PLANTS IN SOUTH ASIA}

DLANT breeding in South Asia has in the past largely been limited to selection in local races, which have the great advantage of being closely adjusted by a long process of natural selection to local climatic conditions. Much more than this is now needed. It is necessary to make large collections of both wild and cultivated forms of economic plants, as well as of crossable wild species in the genus. The species itself, and all other species with which it can exchange genes, becomes a gene pool from which desirable combinations can be synthesized by the new techniques now available. The synthesis of new amphidiploids, the induction of advantageous mutations, and the use of embryo culture to make difficult interspecific crosses possible-all these play a part in modern plant breeding. 